\title{
Exploring beliefs and attitudes of personal service practitioners towards infection control education, based on the Health Belief Model
}

\author{
Keara Shaw \\ Faculty of Education, University of Alberta, Edmonton, AB, Canada.
}

\begin{abstract}
Tattooing, body and ear piercing, hair cutting and hair styling, and esthetic procedures such as manicures, pedicures, and make-up application are popular personal services procedures currently offered to the public. Without proper infection and injury control practices in place, personal service procedures can pose a risk for the spread of communicable disease and (or) the potential for bodily injury. A well-planned standardized education program for personal service practitioners could likely contribute to the control of infection and injury from personal service procedures and be a fiscally responsible means of controlling health care costs. Using the Health Belief Model, this research study aims to explore the attitudes and beliefs of personal service practitioners towards infection control education, as this can provide insightful information for planning a successful education program. Five qualitative, in-person interviews were conducted with personal service practitioners. The results of the interviews indicate that although cost, time, access to education, and language may be barriers to receiving education, the interviewed practitioner still believe that infection control education is extremely important and necessary for client safety, and that the implementation of an effective infection control education program for the personal services industry is essential.
\end{abstract}

Key words: personal services, education, health belief model.

\section{Introduction}

Tattooing, body and ear piercing, hair cutting and hair styling, and esthetic procedures such as manicures, pedicures, and makeup application are popular personal services procedures currently offered to the public (AR 20/2003). Without proper infection and injury control practices in place, personal service procedures can pose a risk for the spread of communicable disease and (or) the potential for bodily injury (Health Canada, 1999). Common diseases that may be associated with personal service procedures include: Human Papilloma virus, Herpes Simplex virus, fungal infections, and skin infections caused by Pseudomonas, Staphylococcus, or Mycobacterium (Alberta Health, 1995). Invasive procedures may contribute to the spread of blood borne infections, such as Hepatitis B virus, Hepatitis C virus, and Human Immunodeficiency virus (Health Canada, 1999). More recently, there have been cases of methicillinresistant Staphylococcus aureus associated with personal service procedures (Huijsdens et al., 2008). Injury to the body such as scarring, keloid formation (Health Canada, 1999), and permanent nerve damage (Brody et al., 2003) may also be a risk associated with undergoing invasive esthetic procedures.

Corresponding author: Keara Shaw (email: Keara.shaw@albertahealth services.ca)

EHR Vol. 59(1) 7-16
There is currently no published data on the total costs associated with infection and injury from personal service procedures, but it is likely placing an unnecessary burden on the health care system. A closely related researched topic area is health care associated infections, which is widely recognized as an important and costly problem for the health care system (PHAC, 2010). Therefore, implementing infection and injury control practices, to prevent disease and injury, is a necessary behaviour for personal service practitioners to follow when performing procedures on clients. Unfortunately, implementation of proper infection and injury control practices in personal service establishments does not always occur.

In Alberta, the Personal Services Regulation (AR 20/2003), under the Public Health Act (R.S.A 2000, cP-37), is in effect to control for infection and injury risks in personal service establishments. Although the regulation helps to enforce some infection and injury control practices, it does not currently require a minimum level of education or competence for personal service practitioners. Regulations and enforcement are more likely to be effective in minimizing risks for infection and injury, when supported with education programs. According to Worp et al. (2006), educational initiatives may increase a practitioner's likelihood of implementing control measures and adhering to the regulation. The requirement of certain business operators to have a minimum level of education to reduce the 
spread of communicable disease is a measure that has been adopted by other Alberta regulations, particularly for food and swimming pool operations (AR 31/2006; AR 293/2006). Similar to these other industries, a well-planned standardized education program recognized by government and the personal services industry could contribute to the control of infection and injury from personal service procedures and would be a fiscally responsible means of controlling health care costs.

Public health departments are increasingly becoming more aware of the shortcomings in the education requirements for personal service practitioners. This results in an emphasis being placed on the development of education programs for the personal services industry. Developing education programs in infection control and injury prevention for the personal services industry is a newer concept, and so it requires careful forethought to improve the chances of the program being successful. An unplanned program may result in a lack of support from key stakeholders and dissatisfied learners. These errors could lead to many more challenges in the future.

To develop a well-planned standardized education program, it is important to understand the attitudes and beliefs of personal service practitioners towards infection control education. This is one of the important stages in program planning, as the program is more likely to be successful and accepted by industry if practitioners' attitudes and beliefs have been taken into account.

A good theoretical framework for exploring the beliefs and attitudes of personal service practitioners towards infection control education is the Health Belief Model (HBM). The HBM is a popular theory used to explain change and maintenance of health-related behaviour and for developing appropriate health behaviour interventions. The HBM constructs are susceptibility, severity, benefits, and barriers to behaviour, cues to action, and self-efficacy (Champion and Skinner, 2008). For example, if a personal service practitioner believes $(i)$ there is a good chance a client could acquire an infection from a personal service, $(i i)$ that that infection could have severe consequences, (iii) that taking action would reduce a client's susceptibility to or the severity of the infection, and (iv) the perceived benefits of taking action outweigh the barriers, such as the cost of action, they are more likely to take action and implement infection control practices to reduce the risks (Champion and Skinner, 2008). Cues to action and self-efficacy also increase the likelihood of adherence to a particular behaviour.

\section{Purpose of the research}

The purpose of this research was to use the constructs of the HBM theory to explore the attitudes and beliefs of personal service practitioners towards infection control education. Trying to understand the attitudes and beliefs of the personal service practitioner can help build support for the program and it can provide the program planner with insightful information to ensure the program is a success. Program planning should not be just a one-off exercise; it should be purposeful and responsive to the needs of the learners and the industry itself (Collier and Smith, 2009). People act and change for personal and different reasons; hence, efforts must be made to understand these reasons and to develop approaches that influence that reasoning and support the change that the industry want to make (Collier and Smith, 2009). Also, because the goal of a public health education program is to foster a change in behaviour, the program must be well planned and foster support from future learners to achieve this. It is known that motivating behaviour change is a complex process, which is why the nature of the problem must be thoroughly researched and the initiative must be based on established theory (Glanz et al., 2008). Engaging the practitioners, garnering their support, and understanding their beliefs and attitudes in the program planning stages can increase the chances the program will be successful.

\section{Procedure}

The data for this study were collected using a qualitative approach. Five personal service practitioners participated in an in-person interview with the researcher at their location of work in May of 2014. Purposeful sampling (McMillan, 2012) was used to select the practitioners for this study because the researcher was seeking individuals who would be particularly informative on this specialized topic area. Names of practitioners who would most likely be informative in this research were provided to the researcher by a local public health inspector who had a working relationship with the practitioners. The researcher recruited the personal service practitioners from four different local personal service businesses in Edmonton, Alberta. The inclusion criteria for selecting practitioners were they were an owner or an employee of a personal service establishment and performed personal service procedures on clients from the public. Five representative categories of the personal services industry were defined, and then one representative from each category was selected to participate in the interviews. The categories were defined as hairstyling, cosmetics, piercing, tattooing, and esthetics based on the categories described in the Alberta Personal Services Regulation (AR 20/2003). The researcher stopped recruiting volunteers once one interview from each category was collected. All practitioners gave their written informed consent to participate in this study.

An interview guide (McMillan, 2012) was created and used to collect the data, so the interview questions were preplanned and relatively standardized for each interview. The interview guide included questions based on each of the constructs described in the HBM theory. Perceived susceptibility and severity questions investigated the practitioners' beliefs on risks of infection and injury associated with personal service procedures. Benefit and barrier questions focused on the practitioners' attitudes towards education courses in infection control and factors that would influence one in taking a course. Cues to action questions focused on attitude towards motivation to learn and self-efficacy focused on factors that influence a person's ability to learn. The interviews were approximately 10 $15 \mathrm{~min}$ in length, were recorded using a digital voice recorder, and subsequently transcribed into a Word document.

\section{Data analysis}

Data analysis was done based on methods described by McMillan (2012). The researcher read through each of the transcripts and 
organized the practitioners' responses into construct categories in accordance with the HBM. Themes within these categories were identified and summarized into etic data, which is the researcher's interpreted summary of the practitioner responses, and supported with emic data, which is the exact quoted information provided by the practitioners (McMillan, 2012). To enhance the validity of study, the research results were member checked (McMillan, 2012), in other words reviewed by each interviewed practitioner to ensure the summary of results accurately reflected their responses to the interview. Member checking was carried out by providing a copy of the interview transcription and results of the research to the interviewed practitioners for review. None of the interviewed practitioners had any amendments to the collected data, nor did they provide additional information after the data collection.

\section{Results}

The results of this study describe the attitudes and beliefs of five different personal services practitioners towards infection control education within the personal services industry, based on the constructs of the HBM. Results from the interviews are summarized into two tables. Table 1 represents the demographic data of the practitioners collected during the interview, including their area of work, type of personal services offered, years of experience, level of education, and whether or not the practitioner had previously completed a course in infection and injury control. The practitioners included one hairstylist, one cosmetician, one piercer, one esthetician, and one tattoo artist. Table 2 is a summary of the beliefs and attitudes of personal service practitioners towards infection control education; it is based on the HBM and summarizes the results in a matrix table, so that each construct from the HBM is represented by each of the five defined categories of the personal services industry.

\section{Discussion}

Engaging in a conversation with practitioners regarding their attitudes and beliefs was important to help determine if an infection and injury control education program for the personal services industry would be accepted and supported by the practitioners. By using an interview style questionnaire to collect information from personal service practitioners, it helps build support for the development of a new education program because it engages the potential learners in conversation and discussion about their own beliefs and needs. Caffarella and Ratcliff-Daffron (2013) state that "establishing a firm base of support for planning and conducting education and training programs is critical for program planners to embrace." Placing emphasis on building relationships with potential practitioners who would participate in the program and listening well to those most affected by the initiative will increase the likelihood of the education program being accepted.

Engaging the learners in the program planning process also helps with program capacity building and sustainability. Sork (2000) states that "if planners aim to promote social transformation and wish to achieve it in an empowering, highly democratic fashion, then planning requires involving those with a stake in the program, engaging them in conversations to arrive at decisions about intentions and actions to be taken, and converting those decisions into program features." Engagement encourages buy-in from the learners, resulting in a better chance that, over time, change will occur. For example if practitioners feel that the money and time they spend on infection control and attending related educational initiatives is beneficial to their business then the program is more likely to succeed.

In addition, exploring practitioners' beliefs and attitudes towards personal services education can provide program planners with insight for developing a successful education program. For example, if the program planner understands the practitioners' beliefs and attitudes they will be better able to

Table 1. Demographics of the interviewed practitioners.

\begin{tabular}{|l|l|l|l|l|l|}
\hline Practitioner & Area of work & Services offered & Experience & Education & $\begin{array}{l}\text { Completed a course } \\
\text { in infection and } \\
\text { injury control }\end{array}$ \\
\hline 1 & $\begin{array}{l}\text { Hair stylist and } \\
\text { beauty salon } \\
\text { owner }\end{array}$ & Cut hair, colour hair & 20 years & Trade certificate in hair & No \\
\hline 2 & Cosmetician & $\begin{array}{l}\text { Brow shaping, eyelash } \\
\text { extension, cosmetic } \\
\text { tattooing, and make-up }\end{array}$ & 18 years & $\begin{array}{l}\text { Trade certificate in hair } \\
\text { and various certificates } \\
\text { in cosmetology }\end{array}$ & $\begin{array}{l}\text { Yes, in the United } \\
\text { States }\end{array}$ \\
\hline 3 & Piercer & $\begin{array}{l}\text { Body piercing and } \\
\text { jewelry changes }\end{array}$ & 6 years & High School & Yes, in Canada \\
\hline 5 & $\begin{array}{l}\text { Esthetics and nail } \\
\text { salon owner }\end{array}$ & Nail services and wax & 15 years & $\begin{array}{l}\text { Bachelor of Education } \\
\text { and Bachelor of } \\
\text { Commerce }\end{array}$ & No \\
\hline Tattoo artist & Tattoos & 23 years & High school & Yes, in Spain \\
\hline
\end{tabular}




\begin{tabular}{|c|c|c|c|c|c|c|}
\hline & Susceptibility & Severity & Benefits & Barriers & Cues to action & Self-efficacy \\
\hline Hairstylist & $\begin{array}{l}\text { Believes there are little to } \\
\text { no risks to client health } \\
\text { associated with hair } \\
\text { cutting and hair } \\
\text { colouring. }\end{array}$ & $\begin{array}{l}\text { Believes that if a client } \\
\text { were to contract an illness } \\
\text { it would cause mild or no } \\
\text { harm to the client. } \\
\text { Believes that any health } \\
\text { risks that may exist would } \\
\text { not have a major impact } \\
\text { on the client's health. }\end{array}$ & $\begin{array}{l}\text { Believes that infection and } \\
\text { injury control in the } \\
\text { personal service } \\
\text { environment is important, } \\
\text { but is not sure there is } \\
\text { much benefit to extra } \\
\text { infection control } \\
\text { education for a hairstylist, } \\
\text { in that there is limited risk } \\
\text { associated with hair } \\
\text { cutting and hair } \\
\text { colouring. } \\
\text { At the same time, the } \\
\text { practitioner stated that it } \\
\text { may be good to know how } \\
\text { to deal with an issue if } \\
\text { something were to come } \\
\text { about. }\end{array}$ & $\begin{array}{l}\text { Time. Believes an infection } \\
\text { control course for a } \\
\text { hairstylist should be } \\
\text { limited to } 1-4 \text { hours. } \\
\text { Money. Suggests the } \\
\text { course should be free. } \\
\text { Access. Not aware of } \\
\text { infection control courses } \\
\text { for personal service } \\
\text { practitioners offered in } \\
\text { Alberta. }\end{array}$ & $\begin{array}{l}\text { Prefers face-to-face } \\
\text { instruction in a classroom. } \\
\text { The practitioner stated } \\
\text { that while social media } \\
\text { may be effective for many, } \\
\text { it is not for her. Prefers } \\
\text { in-person interaction for } \\
\text { getting information. } \\
\text { Believes that infection } \\
\text { control education should } \\
\text { be regulated, especially for } \\
\text { the cosmetic industry, } \\
\text { such as for those who do } \\
\text { permanent make-up. }\end{array}$ & $\begin{array}{l}\text { The practitioner is } \\
\text { comfortable with going } \\
\text { back to a classroom, but } \\
\text { does have some anxiety } \\
\text { with test taking. } \\
\text { The practitioner stated } \\
\text { that she learns best from } \\
\text { seeing and experiencing. } \\
\text { Believes she can learn } \\
\text { more about infection and } \\
\text { injury control. } \\
\text { Believes she is capable } \\
\text { of learning a new skill and } \\
\text { applying it in her everyday } \\
\text { work. }\end{array}$ \\
\hline Cosmetician & $\begin{array}{l}\text { Believes there is a health } \\
\text { risk associated with } \\
\text { cosmetic tattooing if the } \\
\text { proper precautions are } \\
\text { not taken. }\end{array}$ & $\begin{array}{l}\text { Believes the health risks } \\
\text { could potentially be very } \\
\text { serious; the practitioner } \\
\text { stated specific health risks } \\
\text { such as Hepatitis C. } \\
\text { Believes these health risks } \\
\text { could have a serious impact } \\
\text { on a client's overall health, } \\
\text { including their mental } \\
\text { health, just knowing that } \\
\text { they have contracted } \\
\text { something. }\end{array}$ & $\begin{array}{l}\text { Believes that taking an } \\
\text { infection control course } \\
\text { is very important. } \\
\text { The practitioner stated } \\
\text { that it is important to } \\
\text { know how to sanitize } \\
\text { everything, to use gloves, } \\
\text { to change gloves, to use } \\
\text { single use needles, not } \\
\text { to double dip, and to be } \\
\text { careful about what you } \\
\text { touch. }\end{array}$ & $\begin{array}{l}\text { Time. Suggests the course } \\
\text { to be one to two days. } \\
\text { Access. Lack of } \\
\text { availability for infection } \\
\text { control courses in the } \\
\text { province. The practitioner } \\
\text { is not aware of courses } \\
\text { in this subject matter that } \\
\text { can be taken locally. }\end{array}$ & $\begin{array}{l}\text { Believes that instruction } \\
\text { needs to be personal, } \\
\text { face-to-face. Stated that } \\
\text { people take a formal } \\
\text { classroom more serious. } \\
\text { Believes that social media } \\
\text { and pamphlets are less } \\
\text { effective for educating on } \\
\text { infection control practices. } \\
\text { Believes infection control } \\
\text { education should be } \\
\text { regulated. The practitioner } \\
\text { explained that there is a lack } \\
\text { of regulation or certification } \\
\text { requirements for personal } \\
\text { service practitioners. She } \\
\text { said, "anyone with any } \\
\text { machine or anybody who } \\
\text { thinks they can make a } \\
\text { dollar here and there, } \\
\text { technically could do it and } \\
\text { they do do it". } \\
\text { The practitioner thinks that } \\
\text { the certification and } \\
\text { education requirement for }\end{array}$ & $\begin{array}{l}\text { The practitioner is } \\
\text { comfortable with going } \\
\text { back to a classroom, and } \\
\text { is comfortable with test } \\
\text { taking. } \\
\text { The practitioner stated } \\
\text { that she learns best by } \\
\text { experiencing. } \\
\text { Believes she can learn } \\
\text { more about infection and } \\
\text { injury control. } \\
\text { Believes she is capable } \\
\text { of learning a new skill and } \\
\text { applying it in her everyday } \\
\text { work. }\end{array}$ \\
\hline
\end{tabular}




\begin{tabular}{|c|c|c|c|c|c|c|}
\hline & Susceptibility & Severity & Benefits & Barriers & Cues to action & Self-efficacy \\
\hline & & & & & $\begin{array}{l}\text { personal service } \\
\text { practitioners should be } \\
\text { more stringent. }\end{array}$ & \\
\hline Piercer & $\begin{array}{l}\text { Believes that there is little } \\
\text { to no risk when the proper } \\
\text { precautions are taken. But } \\
\text { if no precautions are } \\
\text { taken, then she believes } \\
\text { the risks are extremely } \\
\text { high. } \\
\text { The practitioner listed } \\
\text { various illnesses that } \\
\text { could be passed on to } \\
\text { clients. The practitioner } \\
\text { said, "at the super } \\
\text { extreme, something like } \\
\text { hepatitis, but there's also } \\
\text { things like other blood } \\
\text { borne pathogens and } \\
\text { dermatitis and outbreaks } \\
\text { of herpes". }\end{array}$ & $\begin{array}{l}\text { The practitioner stated } \\
\text { that the severity of the } \\
\text { illness could be mild, } \\
\text { moderate, and serious, } \\
\text { depending on the type } \\
\text { of illness. } \\
\text { In regards to the impact } \\
\text { an infection or injury } \\
\text { could have on a client's } \\
\text { overall health, the } \\
\text { practitioner said, "It } \\
\text { could affect them very } \\
\text { much, physically, and } \\
\text { emotionally, also knowing } \\
\text { that they did contract } \\
\text { something like that from } \\
\text { the service that we } \\
\text { provide. That could } \\
\text { be terrible". }\end{array}$ & $\begin{array}{l}\text { It is important to learn to } \\
\text { spore test the autoclave } \\
\text { machines frequently, wash } \\
\text { hands, change gloves, } \\
\text { prevent cross- } \\
\text { contamination by putting } \\
\text { lots of barriers in place, } \\
\text { clean constantly, do lots } \\
\text { of testing to make sure } \\
\text { equipment is working } \\
\text { properly, and process and } \\
\text { sterilize everything. } \\
\text { "The benefits of a course } \\
\text { are huge, they are } \\
\text { everything. They will just } \\
\text { help you know what you } \\
\text { are doing and protect you } \\
\text { and your client's health." }\end{array}$ & $\begin{array}{l}\text { Time. The course needs } \\
\text { to be scheduled around } \\
\text { customer service hours } \\
\text { (working hours are noon } \\
\text { to eight). And, believes } \\
\text { that a day should be } \\
\text { enough to cover the } \\
\text { information unless it is } \\
\text { a specialized or unique } \\
\text { service, then you might } \\
\text { need an extra day to cover } \\
\text { the appropriate material. } \\
\text { "Anything more than that } \\
\text { might not be totally } \\
\text { necessary." } \\
\text { Money. Believes that cost } \\
\text { could be a barrier if the } \\
\text { course were exorbitantly } \\
\text { priced. Believes that the } \\
\text { course must be reasonably } \\
\text { priced so that personal } \\
\text { service practitioners can } \\
\text { access it. }\end{array}$ & $\begin{array}{l}\text { Believes that face-to-face } \\
\text { instruction, such as in a } \\
\text { classroom or a workshop, } \\
\text { is the best method to } \\
\text { deliver education. Online } \\
\text { instruction could be a } \\
\text { second option. } \\
\text { Believes that pamphlets, } \\
\text { mail outs, and emails } \\
\text { would not be very } \\
\text { effective. The practitioner } \\
\text { said, "Something like just } \\
\text { a handout, you know you } \\
\text { can just toss that in the } \\
\text { garbage. I don't see that } \\
\text { being super effective." } \\
\text { Believes that infection } \\
\text { control education should } \\
\text { be regulated. } \\
\text { Believes that there should } \\
\text { be more stringent } \\
\text { regulation and } \\
\text { certification requirements } \\
\text { of personal service } \\
\text { practitioners, including } \\
\text { estheticians and hair } \\
\text { stylists, and especially } \\
\text { piercers. The practitioner } \\
\text { said, "there is virtually } \\
\text { nothing that we have to } \\
\text { do, in any of these sorts of } \\
\text { field, in our industry, } \\
\text { which is totally crazy." }\end{array}$ & $\begin{array}{l}\text { The practitioner is } \\
\text { comfortable about going } \\
\text { back to a classroom, but } \\
\text { does have some anxiety } \\
\text { about test taking. } \\
\text { The practitioner stated } \\
\text { that she learns best from } \\
\text { doing and experiencing, } \\
\text { but also from listening. }\end{array}$ \\
\hline Esthetician & $\begin{array}{l}\text { Believes that the types } \\
\text { of procedures or services } \\
\text { offered pose potential } \\
\text { health risks. }\end{array}$ & $\begin{array}{l}\text { Believes that the health } \\
\text { risks can lead to serious } \\
\text { problems if the proper } \\
\text { precautions are not taken. }\end{array}$ & $\begin{array}{l}\text { Infection and injury } \\
\text { control education is } \\
\text { important. It is worth the } \\
\text { extra time and money } \\
\text { because the safety of the }\end{array}$ & $\begin{array}{l}\text { Language barriers. For } \\
\text { many practitioners } \\
\text { working in the industry, } \\
\text { English is their second } \\
\text { language. }\end{array}$ & $\begin{array}{l}\text { The course has to be face- } \\
\text { to-face, especially when } \\
\text { you are trying to start a } \\
\text { wave. A workshop would } \\
\text { be good, but it would also }\end{array}$ & $\begin{array}{l}\text { The practitioner is } \\
\text { comfortable about going } \\
\text { back to a classroom, and } \\
\text { is comfortable with test } \\
\text { taking. }\end{array}$ \\
\hline
\end{tabular}




\begin{tabular}{|c|c|c|c|c|c|}
\hline Susceptibility & Severity & Benefits & Barriers & Cues to action & Self-efficacy \\
\hline $\begin{array}{l}\text { The practitioner listed } \\
\text { fungal infections as an } \\
\text { example of the health } \\
\text { risks associated with the } \\
\text { nail industry. Anecdotally, } \\
\text { she has heard that these } \\
\text { types of things are very } \\
\text { common in the nail } \\
\text { industry. } \\
\text { The practitioner did some } \\
\text { research into the health } \\
\text { risk when she put together } \\
\text { her business plan and } \\
\text { found that the number of } \\
\text { people contracting an } \\
\text { illness from one of these } \\
\text { services seems to be } \\
\text { increasing. }\end{array}$ & $\begin{array}{l}\text { The practitioner said, } \\
\text { "For here, definitely mild } \\
\text { or very minimal because } \\
\text { I've done all those } \\
\text { proactive things you } \\
\text { know, doing the } \\
\text { disposable liners and } \\
\text { everything like that, but in } \\
\text { the industry itself it can be } \\
\text { more serious." } \\
\text { She described an extreme } \\
\text { case of having an infection } \\
\text { and having it spread and } \\
\text { then needing to be } \\
\text { amputated. But otherwise } \\
\text { the typical scenario is a } \\
\text { fungal infection which } \\
\text { would need medication } \\
\text { and then maybe laser } \\
\text { surgery. } \\
\text { Believes this can also have } \\
\text { an impact on the clients' } \\
\text { mental well being and } \\
\text { affect them financially. }\end{array}$ & $\begin{array}{l}\text { public is of the utmost } \\
\text { importance. } \\
\text { It's important to know } \\
\text { what spray products to use } \\
\text { to clean, to have an } \\
\text { autoclave machine and } \\
\text { know how to use it, and to } \\
\text { use disposable liners. }\end{array}$ & $\begin{array}{l}\text { Knowledge transfer. The } \\
\text { practitioner said, "There } \\
\text { is no point of educating } \\
\text { when you don't } \\
\text { understand and when } \\
\text { there is nobody there to } \\
\text { help you apply, because } \\
\text { it's very hands on... If you } \\
\text { just give them the } \\
\text { knowledge it's not enough } \\
\text { to transfer into action." } \\
\text { Money and time. The nail } \\
\text { industry is a very } \\
\text { profitable industry that } \\
\text { has never had to take any } \\
\text { education before. So it will } \\
\text { be a challenge to convince } \\
\text { small business owners to } \\
\text { take the time out of their } \\
\text { busy schedules to do a } \\
\text { course as this could } \\
\text { potentially impact their } \\
\text { income for the day. } \\
\text { Suggests that public } \\
\text { health offers the course at } \\
\text { no cost to the business or } \\
\text { it could be just a half day } \\
\text { or even a two hour course } \\
\text { offered by a vocational } \\
\text { college. } \\
\text { Access. The practitioner is } \\
\text { not aware of any } \\
\text { education programs } \\
\text { currently offered to the } \\
\text { industry. }\end{array}$ & $\begin{array}{l}\text { be good to have online } \\
\text { access. } \\
\text { Businesses need an } \\
\text { incentive to get involved. } \\
\text { For example, a sticker in } \\
\text { their business window that } \\
\text { says they are a preferred } \\
\text { business in compliance } \\
\text { with health regulations. } \\
\text { Believes that infection } \\
\text { control education should } \\
\text { be regulated. There also } \\
\text { needs to be a monitoring } \\
\text { system in place in } \\
\text { conjunction with the } \\
\text { education, because } \\
\text { education in infection and } \\
\text { injury control alone would } \\
\text { not be sufficient. } \\
\text { Suggests the education } \\
\text { should be in two stages. } \\
\text { First stage would be to do } \\
\text { a workshop on infection } \\
\text { and injury control. Second } \\
\text { stage would be to have a } \\
\text { person come in after the } \\
\text { fact as a follow up to the } \\
\text { owner to help them with } \\
\text { implementation, such as } \\
\text { assessing the specific tools } \\
\text { they use and santization } \\
\text { procedures. }\end{array}$ & $\begin{array}{l}\text { The practitioner stated } \\
\text { that she learns best from } \\
\text { seeing. } \\
\text { Believes she can learn } \\
\text { more about infection and } \\
\text { injury control. } \\
\text { Believes she is capable of } \\
\text { learning a new skill and } \\
\text { applying it in her everyday } \\
\text { work. }\end{array}$ \\
\hline
\end{tabular}




\begin{tabular}{|c|c|c|c|c|c|c|}
\hline & Susceptibility & Severity & Benefits & Barriers & Cues to action & Self-efficacy \\
\hline Tattoo artist & $\begin{array}{l}\text { The practitioner said, in } \\
\text { reference to contracting } \\
\text { an illness from a tattoo, } \\
\text { "If you don't change your } \\
\text { needles, you don't change } \\
\text { your tubes, you don't } \\
\text { change your tables, and } \\
\text { you don't clean anything } \\
\text { in your shop, 100\%. For } \\
\text { sure. It's like a dentist, if } \\
\text { you don't clean anything } \\
\text { in this place, one guy } \\
\text { could have something the } \\
\text { next guy is going to get } \\
\text { it." } \\
\text { The practitioner listed } \\
\text { health risks, such as } \\
\text { AIDS, Hepatitis, } \\
\text { tuberculosis, and a lot of } \\
\text { other viruses. }\end{array}$ & $\begin{array}{l}\text { Believes that poor } \\
\text { infection control practices } \\
\text { can lead to serious illness. } \\
\text { The practitioner said, } \\
\text { "Hepatitis is with you } \\
\text { forever, AIDS the same. A } \\
\text { deep infection in your arm } \\
\text { can turn into septicemia. } \\
\text { You can lose a lot." } \\
\text { The practitioner also said, } \\
\text { "I don't know anyone who } \\
\text { died from getting a tattoo } \\
\text { but I know they can get } \\
\text { really bad things. } \\
\text { There are bad places out } \\
\text { there. Like a person who } \\
\text { does a tattoo in their } \\
\text { home, with the dog, and } \\
\text { dirty bathroom. I know } \\
\text { one case in Spain where he } \\
\text { tattooed on one person } \\
\text { with Hepatitis and didn't } \\
\text { change the needle and } \\
25 \text { people after that } \\
\text { contracted Hepatitis." }\end{array}$ & $\begin{array}{l}\text { Believes infection and } \\
\text { injury control education is } \\
\text { important. You have to do } \\
\text { the best for your } \\
\text { customers. } \\
\text { Now you have a lot of } \\
\text { information with the } \\
\text { internet. It is important to } \\
\text { stay in touch, read, and } \\
\text { always learn. } \\
\text { The practitioner said, } \\
\text { "Education is never a bad } \\
\text { thing." }\end{array}$ & $\begin{array}{l}\text { Experience. The } \\
\text { practitioner has been } \\
\text { doing this for twenty } \\
\text { years. He already took an } \\
\text { infection and injury } \\
\text { control course } 12 \text { years } \\
\text { ago and does not feel it is } \\
\text { justified for him to take } \\
\text { another course. But he } \\
\text { does recommend the } \\
\text { course for someone just } \\
\text { starting out. } \\
\text { The practitioner said, in } \\
\text { reference to taking } \\
\text { another infection control } \\
\text { course, "Not now, because } \\
\text { nobody has to tell me } \\
\text { what to do. I am more } \\
\text { than twenty years doing } \\
\text { this. I've never had a } \\
\text { problem with this thing. If } \\
\text { someone is going to start } \\
\text { doing tattoos, I would } \\
\text { recommend it of course, } \\
\text { but not for me. I can } \\
\text { always learn something, } \\
\text { but I think it is enough, } \\
\text { you know, what I know... } \\
\text { I don't want to stay in a } \\
\text { course all the time or have } \\
\text { to keep doing something } \\
\text { for my life" } \\
\text { Time. The practitioner } \\
\text { suggests that a couple of } \\
\text { days, one weekend, is } \\
\text { enough. }\end{array}$ & $\begin{array}{l}\text { Believes the most effective } \\
\text { way to communicate } \\
\text { infection control } \\
\text { education is by using } \\
\text { existing industry tools } \\
\text { such as tattoo magazines, } \\
\text { or a presentation at a } \\
\text { convention; small things, } \\
\text { not something overdone. } \\
\text { Suggests the course should } \\
\text { be online. The practitioner } \\
\text { said: "Internet is the } \\
\text { future. You can do Skype, } \\
\text { and talk with someone. } \\
\text { You don't have to move } \\
\text { anywhere and lose your } \\
\text { time." } \\
\text { The practitioner said he } \\
\text { would be motivated to } \\
\text { take another course only if } \\
\text { there were some new } \\
\text { sickness going around then } \\
\text { maybe he would feel he } \\
\text { needs to learn something } \\
\text { new, otherwise it is } \\
\text { enough. } \\
\text { Believes infection and } \\
\text { injury control education } \\
\text { should be regulated for } \\
\text { newcomers to the business, } \\
\text { but after that voluntary. } \\
\text { The practitioner does not } \\
\text { want to have to take a } \\
\text { course regularly. }\end{array}$ & $\begin{array}{l}\text { The practitioner is } \\
\text { comfortable about going } \\
\text { back to a classroom, and is } \\
\text { comfortable with test taking. } \\
\text { The practitioner stated he } \\
\text { learns best by seeing. } \\
\text { Believes he can always } \\
\text { learn more, but thinks he } \\
\text { has learned enough about } \\
\text { infection and injury } \\
\text { control. Quoted as saying: } \\
\text { "It is not super difficult." } \\
\text { Believes more public } \\
\text { education is needed for } \\
\text { self-care after receiving } \\
\text { a service. The tattoo artist } \\
\text { can only do so much and if } \\
\text { the public does not do their } \\
\text { part to take care, they can } \\
\text { still contract an infection. }\end{array}$ \\
\hline
\end{tabular}


tailor the program to suit the needs of the learners. Sorting the practitioners' responses into constructs in accordance with the HBM was the method used to analyze the responses.

The first construct of the HBM is perceived susceptibility. This construct refers to a practitioner's beliefs about the likelihood a client may acquire an infection from a personal service. If a practitioner feels that the risks associated with personal service is high, they will likely be more accepting of a new education program for their industry. The responses to this construct indicate that practitioners felt strongly that personal services pose a high risk for the spread of infection, if control measures are not implemented. Particularly the cosmetician, the esthetician, the piercer, and the tattoo artist perceived that the risk for contracting illness from a personal service is high when the proper precautions are not taken. Only the hairstylist believed that the risks of illness or injury associated with hair cutting and hair colouring were lower. Each interviewed practitioner seemed to be aware of the risks and had implemented some degree of infection control for their business. Because of this they felt the risk for acquiring an infection from their service was low, but they felt strongly that there are still high risks for transmission of infection in other businesses where infection control practices are not properly implemented.

The severity construct of the HBM describes how serious a person believes an illness would be if an infection were acquired. If practitioners do not believe that the severity of infection is high then they may not likely see much benefit to an education program. The responses to severity construct questions show that all the practitioners, except the hairstylist, believed that if an illness were acquired from a personal service the impact could be severe. The piercer, esthetician, and cosmetician all believed that the impact of acquiring an infection would not just result in a physical illness, but that it would be emotionally and mentally damaging as well. The practitioners' responses to the susceptibility and severity of illness questions show that there is support for the development of personal services education programs, in that they believe that if a practitioner lacks the knowledge in this topic area then the risks are high.

Only the hairstylist felt that the severity of illnesses that could be acquired from hairstyling would be low. Based on the hairstylist's response, a hairstylist may not feel the need to take extra education in infection and injury control since their belief that the susceptibility and the severity of illness associated with their types of personal service is fairly low. If hairstylists are included in the program, the program planner should consider how the information would be relatable to a hairstylist. An option could be that the program planner offers different modules of education. In this case, one size may not fit all. There may need to be targeted approached used for different practitioners within the personal services industry. Perhaps separate modules for hairstyling that focus more on the particular issues related with that type of service, so that the hairstylists feels like they are being taught something that is applicable to them.

The benefit construct of the HBM describes the attitudes and beliefs the practitioners have regarding the value an education program has to offer. In other words, what would they gain out of an education program in infection and injury control? The practitioners' responses indicate that the main benefit of the course is improved health protection for their clients, which is of utmost importance. In addition, the perceived benefits of this education are that everyone can benefit from learning and that learning is a lifelong process.

The hairstylist indicated that infection and injury control in the personal services environment is important; however, she is not sure there is added benefit for her to take extra infection control education as they believe there is limited risk with hair cutting and hair colouring. Although, she later went on to say that it may be good to know how to deal with an issue if something were to come about. It is important for the program planner to identify these types of beliefs so they know how to address their audience when presenting a topic. In the case of hairstylist, it may be helpful to present the information as good to know information, especially if they are interested in expanding their business into offering other potential personal services.

The barriers construct within the HBM describes the obstacles a practitioners' may face when accessing or receiving education in infection and injury control. The responses to the questions developed within this construct gives program planners an idea of what they need to overcome when designing the program plan. The interviewed personal service practitioners provided insightful information about some barriers that would prevent them from taking a course. Time, accessibility, and money were common points of concern. If the course is not offered during a convenient time nor offered at a convenient place, or if the course length is too long this could inhibit participation in the course.

The course timing needs to be flexible around a practitioner's schedule. A lot of the practitioners are small business operations, in which they attend to the business daily and have difficulty finding the time to step away from the operation. Also, the course should be planned in consideration of the business hours of the personal services industry, which often include weekend and evening work. Short in-person modules in the morning may work best in that it does not take away a whole day of business, or offering online modules that the practitioner can navigate through on their own time may allow for flexibility. Online education was favoured by the tattoo artist, particularly to enhance the ease of access to information. But all the other practitioners said they prefer to learn in a classroom setting. Most practitioners viewed face-to-face instruction as essential, saying that they needed personal interaction to be engaged in the learning process.

Also, if the course offered is not affordable, this too would be a deterrent to taking the course. Practitioners are looking for relatively inexpensive options for education. A course subsidized by the local health department or low-cost courses could increase the likelihood of personal service practitioners accessing and accepting a new education program.

Language was identified as another barrier to taking an infection control education course. For many practitioners working in the personal services industry, especially within the esthetics industry, English is their second language. If courses 
are offered only in English or do not consider the language limitation, practitioner interest and learning may be lower.

Another one of the barriers mentioned was knowledge transfer. Knowledge transfer occurs when the learner can actually put into practice what was learned as a result of attending an education or training program (Caffarella and Ratcliff-Daffron, 2013). The esthetician's response indicated that practitioners need hands on learning, and practical training, not just the knowledge. There needs to be demonstration and follow-up to help with implementation of what the student learned. The students need assistance to transform what they learned from the classroom into practice, which can be especially true when there is a language barrier.

The results also describe the personal service practitioners' beliefs towards cues to action, for example, what would motivate or facilitate them to learn. Most agreed that face-to-face instruction is necessary to engage the learner, although having access to online education would make the information more readily available. Some suggested having a blended format in which part of the education is delivered in person and the remainder is enhanced with online information. Many of the practitioners did not see social media, handouts, and pamphlets as an effective education intervention because people just glance at them and then toss them. But these forms of communication could be used as a cue to action. Marketing of available courses is essential to make the practitioners aware of the program's availability. The esthetician suggested that there needs to be incentives for practitioners to learn more about infection control practices, such as a recognition sticker for completing infection control education that a business owner could place in their storefront window.

Most interviewed practitioners also agreed that infection control education should be regulated and required rather than just relying on voluntary participation. If the course were voluntary the participation in the program would likely be a lot lower and there would be less of an increase in infection and injury control knowledge within the industry.

Finally the results described the personal services practitioners' beliefs about their self-efficacy. Self-efficacy is an individual's perception as to whether an intervention will actually make a difference in outcomes. So those with a high self-efficacy expect their efforts to produce favorable outcomes, whereas those with low self-efficacy tend to believe their efforts will be in vain. Those with high self-efficacy are more likely to overcome barriers than those with low self-efficacy (Bandura, 2004). Indicators of the practitioners' self-efficacy are how they feel about returning to a classroom, taking a test, and their preferred learning style. The results show that most practitioners feel comfortable with going back to a classroom, and feel that they could learn more on infection control. Although they are comfortable with the classroom setting, some practitioners felt nervous about taking a test, whereas others were not worried about it. The program planner needs to consider that the assessment portion of the education course must be developed with the end learner in mind. Although some may be nervous with taking a test, they all believe that they are capable of learning new skills and could apply it in their everyday work.
Participants also provided insight on their ability to learn and what learning style was best suited to their needs. The responses show that learning styles vary amongst the practitioners, but seeing, doing, and experiencing were common answers for how the practitioners think they learn best. So an important consideration in the program planning would be to include visual demonstrations in the courses, lots of pictures, and perhaps opportunities to practice certain skills, such as how to use an autoclave machine or practicing aseptic technique. With this information one can conclude that practical training, with hands-on examples in the course, would be of value.

When planning an educational initiative for the personal services industry, the program planner may want to consider the practitioner's previous experience in infection control. For example, the tattoo artist with 23 years of experience and previous education in infection control does not believe that they need to take yet another course on this topic. Rather, he believes that infection control education is necessary for those with little experience or no previous education in infection control. Even for those who believe the risks associated with personal services are high, if they already implement infection control practices, many did not feel the need to take extra education on this subject. But they do believe that other practitioners need to be brought up to the same level of understanding, especially since they perceive the susceptibility and severity of illness as high in situations where the practitioner is untrained and lacks knowledge. Different levels or formats of education may be considered so that more experienced learners still feel engaged in the learning process and feel that there is value in the education program being offered. It is important for a program planner to be aware of its learner's interest in a program and the belief in its necessity for the program to be successful.

\section{Challenges and limitations}

Those who volunteered to participate in this study tended to have an interest in, or at least an understanding of, infection control, which provided rich information but also introduced bias to the study in that their beliefs and attitudes are likely to be more positive than practitioners who do not have an understanding of or interest in infection control. Volunteers tend to be more informed about the topic area and already educated in infection control practices. Therefore, this study does not reflect the general beliefs and attitudes of practitioners in the personal services industry as a whole where many practitioners are not as familiar with infection control practices.

The samples size for this study was small owing to limited time and resources, but it is recommended that further interviews be conducted to expand on beliefs and attitudes of personal service practitioners. Focus groups rather than interviews might also be a good way to get discussions going and create acceptance for an education program within the industry, as well as gain a larger perspective on this topic.

Another limitation to this study was that the interview guide was not piloted before being used to conduct the five interviews. After completing a few of the interviews, it was evident that there were some questions in the guide that could have been adjusted to extract longer answers from the practitioner rather than simply 
yes or no answers. Improving the questionnaire to extract longer answers and interviewing a few more personal services practitioners is strongly encouraged to understand and engage more learners in the planning process.

\section{Conclusion}

The personal services industry is growing rapidly, increasing the potential to spread infection and cause injury if the proper control measures are not in place. Infection and injury can be minimized, especially with the implementation of effective education programs. Researching and engaging the learners in the development process is essential to gain support and increase the effectiveness of a program. The HBM was the theoretical framework used in this study to understand the practitioners and potential future program learners' attitudes and beliefs towards infection and injury control education. The results provide program planners with key information to start the planning process. The interviews indicate that although cost, time, access to education, and language, amongst others, may be barriers to receiving education, the practitioners still believe that infection control education within the personal services industry would be an added benefit and is necessary for client safety.

\section{References}

Alberta Health. 1995. Health standards and guidelines for personal services. Government of Alberta.

Bandura, A. 2004. Health promotion by social cognitive means. Health Educ. Behav., 31: 143-164. doi:10.1177/1090198104263660.

Brody, H.J., Geronemus, R.G., and Farris, P.K. 2003. Beauty versus medicine: The nonphysician practice of dermatologic surgery. Dermatol. Surg., 29: 319-324. doi:0.1046/j.1524-4725.2003.29088.x.

Caffarella, R.S. and Ratcliff-Daffron, S. 2013. Planning programs for adult learners: A practical guide. 3rd ed. San Francisco, CA: Jossey-Bass.

Champion, V.L. and Skinner, C.S. 2008. The health belief model. In K. Glanz, B.K. Rimer, and K. Viswanath, (Eds.). Health behaviour and health education: Theory, research and practice (pp. 45-66). San Francisco, CA: Jossey Bass.
Collier, G., and Smith, P. 2009. Beyond lip service: A council approach to planning for behaviour change. Aust. J. Environ. Educ., 25: 129-138. doi:10.1017/S081406260000046X.

Glanz, K., Rimer, B.K. and Viswanath, K. 2008. The scope of health behavior and health education. In K. Glanz, B.K. Rimer, and K. Viswanath, (Eds.), Health behaviour and health education: Theory, research and practice (pp. 3-22). San Francisco, CA: Jossey Bass.

Health Canada. 1999. Infection prevention and control practices for personal services: Tattooing, ear/body piercing, and electrolysis. Can. Commun. Dis. Rep. 25(Suppl 3). Available at https://www. gov.mb.ca/health/publichealth/environmentalhealth/protection/ docs/11884169_25s3.pdf. (Accessed 3 March 2016.)

Huijsdens, X.W., Janssen, M., Renders, N.H., Leenders, A., vanWijk, P., van Santen Verheuvel, M.G., et al. 2008. Methicillan-resistant Staphylococcus aureus in a beauty salon, the Netherlands. Emerg. Infect. Dis., 14(11): 1797-1799. doi 10.320/eid1411.071297.

Food regulation. Alberta regulation 31/2006. Available at http:// www.qp.alberta.ca/documents/Regs/2006_031.pdf. (Accessed 3 March 2016.)

McMillan, J.H. 2012. Educational research: Fundamentals for the consumer. 6th ed. Boston, MA: Pearson Education Inc.

Personal services regulation. Alberta regulation 20/2003. Available at http://www.qp.alberta.ca/documents/Regs/2003_020.pdf. (Accessed 3 March 2016.)

Public Health Act, R.S.A. 2000, cP-37. Available at http://www.qp. alberta.ca/documents/Acts/P37.pdf. (Accessed 3 March 2016.)

Public Health Agency of Canada. 2010. Essential resources for effective infection prevention and control programs: A matter of patient safety a discussion paper. Available at http://www.phacaspc.gc.ca/nois-sinp/guide/ps-sp/partI-eng.php\#b11. (Accessed 3 March 2016.)

Sork, T.J. 2000. Planning educational programs. In A.L. Wilson and E. Hayes, (Eds.). Handbook of adult and continuing education (pp. 171-191). San Francisco, CA: Jossey-Bass.

Swimming pool, wading pool and water spray park regulation. Alberta regulation 293/2006.

Worp, J., Boonstra, A., Coutinho, R.A., and Ven den Hoek, J.A.R. 2006. Tattooing, permanent makeup and piercing in Amsterdam: Guidelines, legislation and monitoring. Euro Surveill., 11(1): 34-36. 